\title{
IMPLEMENTASI E-COURT DALAM MEWUJUDKAN PENYELESAIAN PERKARA PERDATA YANG EFEKTIF DAN EFISIEN ${ }^{1}$
}

\author{
Zil Aidi \\ Fakultas Hukum, Universitas Diponegoro \\ Jl. Prof. Soedarto, Tembalang, Semarang \\ zil.aidi93@gmail.com
}

\begin{abstract}
This empirical juridical qualitative research carried out in Palembang and Surabaya District Courts shows the application of e-court, in general, can contribute to judicial efficiency. This condition is seen in all civil case registrations through advocates in both PNs, which have been carried out through e-filing, as well as the estimation and payment of court fees that have used $e$-SKUM and e-payment. The use of e-summons and e-litigation has not been implemented because judicial users are still reluctant to use the feature. Moreover, the regulation of esummons deviates the provisions in the HIR and RBG, but this condition is understandable considering the process of establishing a new civil procedural law requires a lengthy process while increasing the judicial efficiency is urgently needed.
\end{abstract}

Keywords: Civil Procedural Law; E-Court; E-Summons

\begin{abstract}
Abstrak
Penelitian kualitatif yang bersifat yuridis empiris ini dilaksanakan di Pengadilan Negeri (PN) Palembang dan Surabaya menunjukkan bahwa penerapan e-court secara umum dapat berkontribusi pada efisiensi peradilan. Kondisi ini terlihat pada seluruh pendaftaran perkara perdata yang melalui kuasa hukum di kedua PN sudah dilakukan melalui $e$-filing, begitu juga dengan taksiran dan pembayaran biaya perkara yang sudah menggunakan $e$-SKUM dan $e$ payment. Penggunaan e-summons dan e-litigation belum terlaksana dikarenakan pengguna peradilan masih enggan untuk menggunakan fitur tersebut. Hasil penelitian juga menunjukkan bahwa pengaturan mengenai e-summons menyimpangi ketentuan dalam HIR dan RBG terkait pemanggilan para pihak, namun kondisi ini dapat dimaklumi mengingat proses pembentukan undang-undang hukum acara perdata yang baru membutuhkan proses yang panjang sementara peningkatan efektifitas dan efisiensi peradilan dibutuhkan segera.
\end{abstract}

Kata kunci: Hukum Acara Perdata; E-Court; E-Summons

\footnotetext{
${ }^{1}$ Artikel ini merupakan hasil penelitian Non PNBP Fakultas Hukum Universitas Diponegoro tahun 2019.
} 


\section{A. Pendahuluan}

Peradilan di Indonesia menganut suatu asas yang bernama contante justitie atau asas peradilan sederhana, cepat dan biaya ringan sebagaimana diatur dalam dalam Undang - Undang No. 48 Tahun 2009 tentang Kekuasaan Kehakiman. Makna dari asas ini adalah proses peradilan yang tidak berbelit-belit, acaranya jelas, mudah dipahami dan biaya yang terjangkau oleh masyarakat tingkat bawah sekalipun (Hairi, 2011).

Pada tataran realitas asas tersebut belum dapat terlaksana sepenuhnya pada peradilan di Indonesia. Robert N. Cole-O Lee Reed berpendapat bahwasanya lembaga peradilan dalam menyelesaikan sengketa kerap mengalami beban yang terlalu padat, lamban dan buang waktu, biaya mahal dan kurang tanggap terhadap kepentingan umum, atau dianggap terlampau formalistis dan teknis (Cole-O Lee, 1986).

Sejalan dengan hal tersebut, hasil riset Masyarakat Pemantau Peradilan Indonesia (MaPPI) menyatakan pengadilan dari sisi pelayanan publik memiliki kelemahan sebagai berikut (Hidayat, 2019): (1) Ketepatan waktu dan jadwal persidangan; (2) Ketersediaan layanan informasi pengadilan yang tidak merata; (3) Masih maraknya pungutan liar pada proses administrasi perkara di pengadilan.

Berangkat dari realitas tersebut, untuk mewujudkan proses peradilan yang sederhana, cepat dan biaya ringan serta sebagai wujud responsif atas tuntutan perkembangan zaman yang mengharuskan adanya pelayanan administratif yang lebih efektif dan efisien, Mahkamah Agung (MA) melalui Peraturan Mahkamah Agung (PERMA) Nomor 1 Tahun 2019 tentang Administrasi Perkara dan Persidangan di Pengadilan Secara Elektronik yang menggantikan PERMA No. 3 Tahun 2018 tentang Administrasi Perkara di Pengadilan Secara Elektronik mengeluarkan sistem $e$ court.

E-court adalah sebuah instrumen pengadilan sebagai bentuk pelayanan terhadap masyarakat dalam hal pendaftaran perkara secara online (e-filing), taksiran panjar biaya secara elektronik (e-SKUM), pembayaran panjar biaya secara online $(e$ payment), pemanggilan pihak secara online (e-summons) dan persidangan secara online (e-litigation) (Mahkamah Agung, 2019a). Lingkungan peradilan yang menyediakan $e$ court adalah Pengadilan Negeri, Pengadilan Agama/Mahkamah Syariah, Pengadilan Militer dan Pengadilan Tata Usaha Negara.

Saat ini layanan e-court sudah tersedia di seluruh lingkungan peradilan umum di Indonesia yakni sebanyak 382 (tiga ratus delapan puluh dua) pengadilan. Per 10 Oktober 2019 pada lingkungan peradilan umum, Pengadilan Negeri (PN) yang paling banyak mendapatkan nomor perkara perdata melalui e-court adalah PN Surabaya sebanyak 686 perkara, PN Tangerang sebanyak 384 perkara dan PN Palembang sebanyak 238 perkara (Mahkamah Agung, 2019b).

Berdasarkan data tersebut penting untuk diteliti dan dianalisa sejauh mana implementasi e-court dalam mewujudkan efektifitas dan efisiensi perkara perdata di pengadilan, dalam penelitian ini adalah PN Surabaya dan PN Palembang selaku dua PN dengan jumlah pendaftaran perkara terbanyak di Indonesia.

Selanjutnya, terdapat isu hukum yang penting untuk diteliti yakni terkait pemanggilan para pihak secara online $(e-$ summons) sebagai salah satu fitur dalam $e$ court. E-summons memiliki definisi tersendiri terkait kapan suatu panggilan kepada para pihak dapat dikatakan sah dan patut, yakni sepanjang panggilan/pemberitahuan tersebut terkirim ke domisili elektronik pihak yang bersangkutan.

Hal ini berbeda dengan definisi panggilan sah dan patut yang selama ini berlaku di dalam beberapa pasal HIR dan RBG. HIR dan RBG pada pokoknya mempersyaratkan 3 kriteria harus terpenuhi agar panggilan dapat dikatakan sah dan patut, yakni, kriteria siapa yang berwenang untuk melakukan pemanggilan, kriteria 
jangka waktu pemanggilan dan kriteria cara pemanggilan.

Berdasarkan pemaparan di atas maka penelitian ini mengangkat rumusan masalah sebagai berikut: (1) Bagaimana penerapan dari e-court dalam mewujudkan peradilan yang efektif dan efisien? (2) Bagaimana implikasi yuridis dari e-summons sebagai salah satu fitur dalam e-court terkait proses pemanggilan para pihak dalam persidangan?

\section{B. Metode Penelitian}

Penelitian pada hakikatnya adalah suatu kegiatan yang mencari kebenaran dari suatu ilmu pengetahuan, dimana penelitian itu lahir dari adanya keraguan atau keingintahuan terhadap suatu masalah (Asikin, 2004).

Penelitian ini menggunakan pendekatan yuridis empiris yang melihat kenyataan hukum di dalam masyarakat terkait penerapan dari e-court dalam mewujudkan peradilan yang efektif dan efisien dan implikasi yuridis dari e-summons sebagai salah satu fitur dalam $e$-court terkait proses pemanggilan para pihak dalam persidangan.

Selanjutnya, digunakan analisis data yang bersifat kualitatif. Data kualitatif dalam hal ini berupa kata-kata, sehingga laporan penelitian akan berisi kutipan-kutipan data untuk memberi gambaran penyajian yang berasal dari wawancara dan beberapa catatan lapangan.

\section{Hasil dan Pembahasan}

1. Penerapan E-Court di Pengadilan Negeri Palembang \& Pengadilan Negeri Surabaya
a. Pengadilan Negeri (PN) Palembang
PN Palembang sudah menyediakan layanan $e$-court secara efektif per bulan Oktober 2018. Dengan perincian sebagai berikut (Prasetyo, 2019):

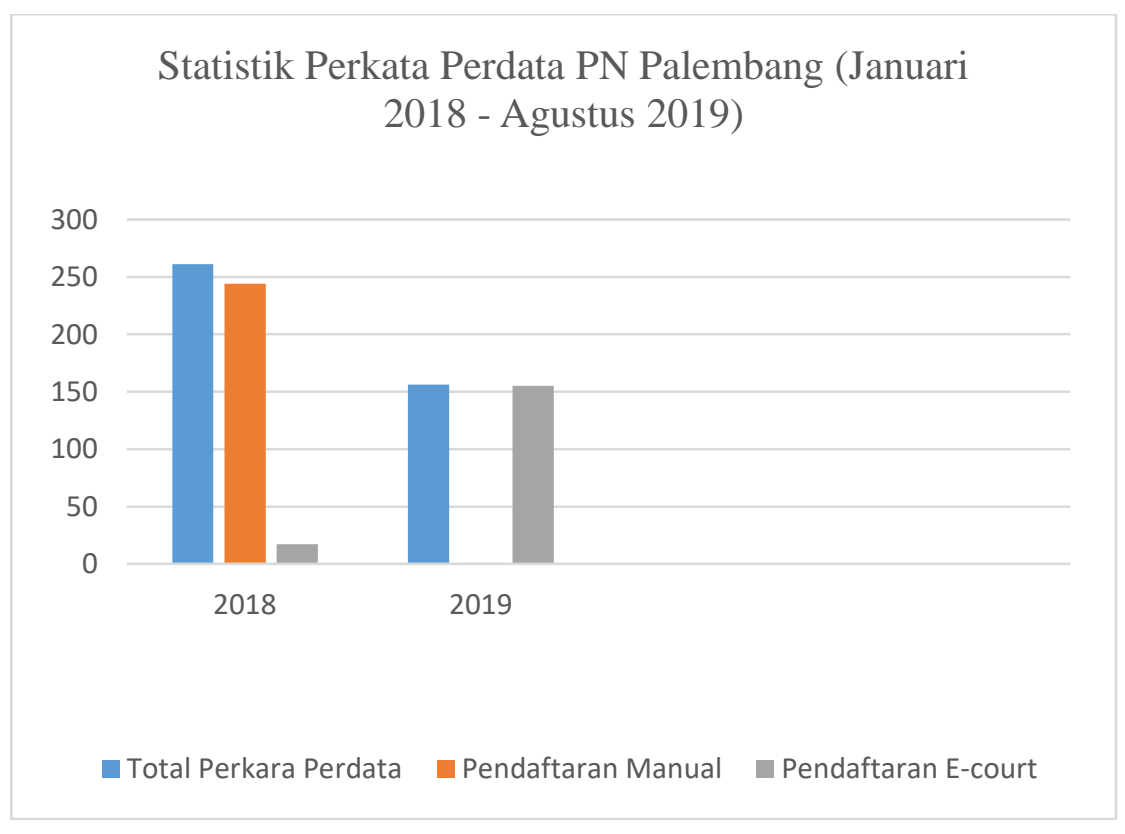

Tabel 1

Statistik Perkara Perdata di PN Palembang (Januari 2018 - Agustus 2019) 
Tabel di atas menunjukkan bahwa di tahun 2018 dari total 261 perkara perdata yang masuk di PN Palembang, hanya 17 yang menggunakan e-court dan sisanya sejumlah 244 perkara menggunakan pendaftaran secara manual ke PN Palembang. Kondisi ini sesungguhnya dapat dimaklumi mengingat landasan hukum pertama yang mengatur e-court yakni PERMA No. 3 Tahun 2018 tentang Administrasi Perkara di Pengadilan Secara Elektronik oleh MA diundangkan baru pada tanggal tanggal 4 April 2018.

Kondisi berbeda terlihat pada tahun 2019, hingga bulan Agustus dari total 156 perkara perdata yang masuk ke PN Palembang 155 di antaranya telah melalui $e$-court. Adapun 1 perkara yang tidak melalui $e$-court adalah perkara perkara perdata yang tanpa menggunakan advokat.

Alasan pertama yang mendasari meningkat drastisnya pengguna layanan e-court tahun 2019 di PN Palembang adalah adanya kebijakan dari Ketua PN Palembang yang mewajibkan setiap perkara perdata yang didampingi atau dikuasakan pada advokat maka harus melalui e-court dan tidak akan dilayani jika menggunakan jalur pendaftaran perkara biasa secara manual.

Alasan kedua adalah telah mulai dilakukannya sosialisasi oleh PN Palembang kepada para pengguna pengadilan, terkhususnya kepada para advokat. PN Palembang beberapa kali telah melaksanakan sosialisasi kepada para advokat tentang e-court dan sekaligus memandu para advokat untuk membuat akun e-court. Selain itu juga sosialisasi dilakukan dalam bentuk pendirian pojok informasi dan layanan $e$-court di PN Palembang guna memudahkan akses informasi seputar $e$ court bagi para pengguna peradilan.

Selanjutnya, Bapak Adi Prasetyo, S.H., M.H. selaku Hakim PN Palembang menyatakan bahwasanya pelaksanaan e-court di PN Palembang secara umum sudah dapat berkontribusi dalam mewujudkan efisiensi dan efektifitas dalam peradilan (Prasetyo, 2019). Efisiensi yang dimaksud adalah sebagai berikut: (1) Mempermudah proses pendaftaran dan pembayaran perkara karena berbasis online (e-filing) dan (e-payment) sehingga bisa dilakukan pendaftaran dan pembayaran dimana saja tanpa harus mengantri di pengadilan; (2) Dokumen perkara terarsip dengan baik dan dapat diakses dari mana saja karena berbasis online.

Meskipun sudah relatif baik, namun pelaksanaan e-court di PN Palembang barulah sebatas pada fitur $e$-filing, $e$ SKUM dan e-payment. Sedangkan untuk fitur e-summons dan e-litigation belum dapat terlaksana di PN Palembang karena adanya keengganan dari para pihak untuk dipanggil dan beracara di pengadilan secara elektronik.

Tanpa adanya persetujuan dari pihak untuk dipanggil secara elektronik maka e-summons tidak akan dapat untuk dilaksanakan. Begitu juga dengan $e$ litigation tanpa adanya consent atau persetujuan dari pihak untuk bersidang secara elektronik tentu penyampaian jawaban, replik, duplik, pemeriksaan saksi atau ahli secara elektronik hingga pembacaan putusan secara elektronik sebagai bagian dari e-litigation tentu tidak dapat dilaksanakan.

Hal ini sejalan dengan Pasal 15 Ayat (1) Huruf b jo. Pasal 20 Ayat (1) PERMA No. 1 Tahun 2019 yang memang secara limitatif mempersyaratkan persetujuan para pihak dalam penggunaan e-summons dan e-litigation. Dalam praktiknya para pihak akan diminta mengisi dan menandatangani formulir "Persetujuan Para Pihak Untuk Beracara Secara Elektronik".

Keengganan para pihak untuk dipanggil dan beracara secara elektronik 
diakibatkan oleh masih adanya ketidakpahaman yang mengakibatkan pengguna peradilan menjadi khawatir ketika panggilan sidang ataupun dokumen perkara tidak sampai karena semuanya tidak berbentuk fisik melainkan berbasis elektronik atau online (Prasetyo, 2019).

Menyikapi kondisi ini PN Palembang perlu untuk kembali menggencarkan sosialisasi kepada masyarakat mengenai kemudahan dari e-court terkhususnya terkait fitur e-litigation dan e-summons agar masyarakat tertarik untuk menggunakan fitur -fitur tersebut.
Terkhusus untuk e-litigation yang terkait dengan pemeriksaan saksi atau ahli secara elektronik melalui media komunikasi audio visual yang disediakan oleh pengadilan masih belum dapat terlaksana juga disebabkan oleh belum tersedianya infrastruktur penunjang di PN Palembang (Prasetyo, 2019).

b. Pengadilan Negeri (PN) Surabaya

PN Surabaya telah menyediakan layanan $e$-court secara efektif per bulan Juli 2018 dengan rincian sebagai berikut (Wibowo, 2019):

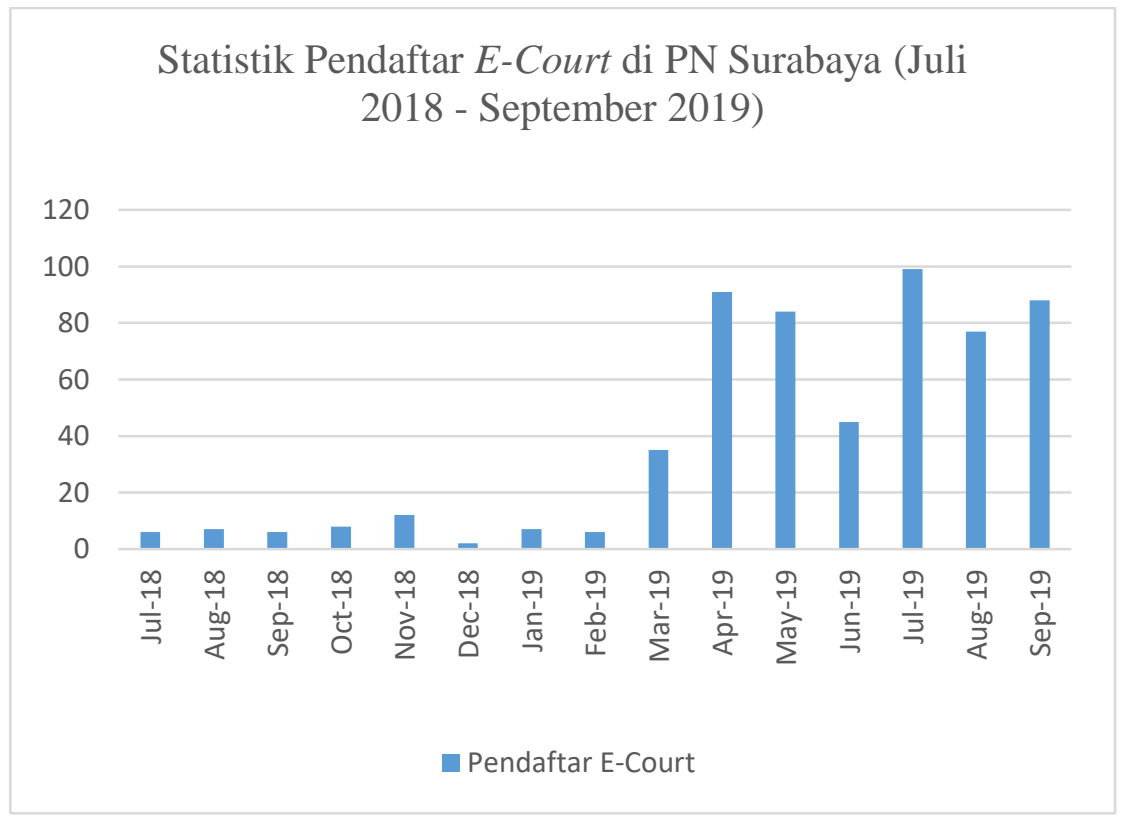

Tabel 2

Statistik Pendaftar E-Court di PN Surabaya (Juli 2018 - September 2019)

Tabel di atas menggambarkan bahwa jumlah terendah penggunaan $e$-court di PN Surabaya adalah pada bulan Desember 2018, yakni hanya 2 perkara saja. Sedangkan jumlah tertinggi penggunaan e-court di PN Surabaya adalah pada bulan Juli 2019 yakni sebanyak 99 perkara. Adapun, total jumlah pendaftaran perkara melalui $e$ court di PN Surabaya adalah sejumlah
573 perkara dengan rata-rata pendaftaran perkara per bulannya adalah sejumlah 38 perkara.

Jumlah perkara yang terdaftar melalui e-court di PN Surabaya merupakan yang tertinggi di seluruh lingkungan peradilan umum Indonesia. Hal ini terwujud karena adanya Surat Keputusan dari Ketua PN Surabaya yang mewajibkan setiap pendaftaran 
perkara perdata yang menggunakan kuasa hukum melalui e-court. Selain itu, keberadaan pojok e-court di PN Surabaya juga berkontribusi dalam meningkatkan akses dan pemahaman masyarakat terhadap $e$-court.

Meskipun, secara kuantitatif jumlah pengguna e-court di PN Surabaya adalah yang tertinggi se-Indonesia namun fitur e-court yang dapat terlaksana baru lah sebatas e-filing, $e$ SKUM dan e-payment. Sedangkan untuk fitur e-summons dan e-litigation belum dapat terlaksana secara penuh di PN Surabaya. Sejauh ini baru 1 perkara yang mana pihaknya bersedia dipanggil dan bersidang secara elektronik (Wibowo, 2019).

E-summons dan e-litigation di PN Surabaya belum terlaksana dikarenakan masih kurangnya pemahaman masyarakat mengenai benefit dari kedua fitur tersebut yang bermuara pada penolakan untuk menggunakan (Wibowo, 2019).

Sebagaimana yang sudah disampaikan sebelumnya sebagaimana di atur dalam Pasal 15 Ayat (1) Huruf b jo. Pasal 20 Ayat (1) PERMA No. 1 Tahun 2019 tanpa persetujuan para pihak maka e-summons dan e-litigation tidak dapat terlaksana.

Fitur e-litigation belum dapat terlaksana di PN Surabaya selain disebabkan oleh keengganan para pihak juga disebabkan oleh belum tersedianya infrastruktur yang menunjang $e$ litigation, seperti keberadaan fasilitas pemeriksaan saksi atau ahli secara elektronik melalui media komunikasi audio visual.

Meskipun masih memiliki kekurangan, namun penerapan e-court di PN Surabaya secara umum telah dapat berkontribusi dalam menciptakan efisiensi dan efektifitas peradilan. Hal ini karena dengan adanya sistem $e$ filing, e-SKUM dan e-payment pada $e$ court maka sedikit banyak dapat mengurai antrian para pengguna peradilan di PN Surabaya karena $e$ court dapat diakses dimana saja tanpa harus datang ke pengadilan (Wibowo, 2019).

\section{Implikasi Yuridis E-Summons Terhadap Panggilan Sah dan Patut}

Hukum acara perdata yang saat ini berlaku di Indonesia adalah warisan dari penjajah Hindia Belanda. Sejarah mencatat hukum acara yang berlaku bagi golongan eropa adalah Reglement op de burgerlijk rechtsvordering (BRv) dimana forum peradilannya bernama Raad Van Justitie.

Sedangkan hukum acara perdata yang berlaku untuk golongan bumiputera dan timur asing adalah HIR (Herziene Indonesische Reglement) bagi yang berada di Pulau Jawa dan Madura, sedangkan bagi yang berada di luar Pulau Jawa dan Madura yang berlaku adalah RBG (Rechtsreglement voor De Buitengewesten). Adapun forum peradilan bagi golongan bumiputera dan timur asing bernama Landraad. Landraad inilah yang menjadi cikal bakal pengadilan negeri yang dikenal dewasa ini.

Landasan hukum masih tetap berlakunya HIR dan RBG hingga saat ini adalah Aturan Peralihan Pasal II dan IV Undang-Undang Dasar Republik Indonesia tertanggal 18 Agustus 1945 jo Pasal 5 dan 6 Undang - Undang Darurat No. 1 Tahun 1951 tentang Tindakan-Tindakan Sementara Untuk Menyelenggarakan Kesatuan Susunan Kekuasaan dan Acara PengadilanPengadilan Sipil. Undang - undang tersebut yang secara jelas menyatakan bahwa HIR dan RBG masih tetap berlaku sebagai peraturan hukum acara di muka pengadilan negeri untuk semua golongan penduduk (semua warga negara Indonesia) (Riyanto, 2019).

Salah satu aturan dalam HIR dan RBG yang masih berlaku hingga saat ini adalah terkait tata cara pemanggilan pihak ke pengadilan, baik itu penggugat, tergugat, saksi harus memenuhi kriteria panggilan sah dan patut sebagaimana terdapat pada 3 kriteria ini (Djais, 2012): (a) Kriteria Siapa Yang Memanggil: Pasal 388 jo. Pasal 390 
ayat (1) HIR dan Pasal 711 jo. Pasal 718 RBG menyatakan bahwa pemanggilan dilakukan oleh Jurusita dengan menyerahkan surat panggilan (exploit) kepada yang bersangkutan; (b) Kriteria Cara Pemanggilan: Prosedur pemanggilan terdiri atas dua jenis, panggilan biasa dan panggilan umum. Panggilan biasa sebagaimana diatur dalam 390 ayat (1) dan ayat (3) HIR serta pasal 718 ayat (1) dan ayat (3) RBG dilakukan dengan dua cara, yaitu diserahkan langsung oleh Jurusita kepada yang bersangkutan sendiri atau oleh Jurusita diserahkan kepada Kepala Desa. Panggilan umum juga dapat dilakukan dengan dua cara yakni, menyerahkan exploit kepada Bupati atau Walikota yang kemudian memerintahkan exploit itu ditempelkan di pintu pengadilan negeri bersangkutan dan juga dapat dilakukan dengan pengumuman lewat papan pengumuman di pengadilan serta mengumumkan lewat media massa; (c) Kriteria Tenggang Waktu Pemanggilan: Pasal 122 HIR jo. Pasal 146 RBG menyatakan bahwa pemanggilan sekurangkurangnya 3 hari kerja sebelum hari sidang.

Panggilan yang sah dan patut adalah suatu sarana guna menjamin agar pengadilan mengirimkan panggilan terhadap para pihak yang terlibat dalam suatu perkara secara tertib dan prosedural serta tidak sewenang wenang.

Panggilan yang sah dan patut sangat berperan penting dalam kelanjutan perkara, karena jika telah dipanggil secara sah dan patut namun pihak tidak hadir di persidangan maka terdapat konsekuensi hukum yang menantinya. Jika yang tidak hadir adalah penggugat maka konsekuensinya adalah hakim dapat memutus gugatan gugur, sebaliknya jika yang tidak hadir adalah tergugat, maka hakim dapat memutus verstek.

Pengaturan mengenai panggilan sah dan patut dalam HIR dan RBG pada dasarnya sudah cukup baik dalam melindungi kepentingan pihak yang hendak dipanggil. Namun terdapat beberapa kekurangan terkait konsepsi ini.
Pertama adalah terdapatnya suatu celah hukum yakni terkait dengan panggilan umum yang dapat diserahkan kepada Kepala Desa atau Lurah dalam hal pihak tidak ketahui domisilinya. HIR dan RBG menyatakan bahwasanya cukup dengan menyerahkan exploit kepada Kepala Desa atau Lurah maka panggilan itu dinyatakan sah dan patut tanpa adanya kewajiban dari Jurusita untuk memastikan apakah Kepala Desa atau Lurah benar - benar menyerahkan panggilan tersebut kepada yang bersangkutan. Kondisi ini tentu merugikan pihak yang dipanggil karena bisa saja dia tidak hadir bukan karena keinginannya, namun karena Kepala Desa atau Lurah tidak menyerahkan exploit kepadanya.

Kedua adalah terkait biaya yang ditimbulkan oleh panggilan sah dan patut. Mobilisasi Jurusita dari pengadilan ke domisili pihak tentu membutuhkan biaya yang tidak sedikit, terlebih jika jarak dari antara pengadilan dengan domisili pihak berjauhan. Beban biaya ini tentunya memberatkan para pihak karena merakalah yang menanggung biaya tersebut.

Keberadaan biaya pemanggilan yang tidak sedikit ini tentunya merupakan suatu hambatan bagi MA untuk mewujudkan peradilan yang sederhana, cepat dan berbiaya murah. Berdasarkan kondisi inilah MA meluncurkan sistem $e$-court yang mana salah satunya terdapat fitur pemanggilan pihak secara elektronik atau e-summons yang diharapkan dapat berkontribusi dalam mewujudkan efisiensi dan efektifitas peradilan.

Panggilan secara elektronik atau $e$ summons diatur dalam Pasal $15-17$ PERMA No. 1 Tahun 2019. Pada pokoknya e-summons memungkinkan pemanggilan para pihak dikirim secara online kepada domisili elektroniknya melalui akun $e$-court yang dimiliki oleh pihak. Adapun definisi dari domisili elektronik yakni domisili para pihak berupa alamat surat elektronik dan/atau nomor telepon seluler yang telah terverifikasi.

Berikutnya, Pasal 18 PERMA No. 1 Tahun 2019 pada pokoknya menyatakan 
bahwa panggilan/pemberitahuan secara elektronik merupakan panggilan/pemberitahuan yang sah dan patut, sepanjang panggilan/pemberitahuan tersebut terkirim ke domisili elektronik dalam tenggang waktu yang ditentukan oleh undang - undang.

Dapat terlihat bahwasanya pengaturan mengenai panggilan secara elektronik yang dianggap sebagai panggilan sah dan patut adalah berbeda dengan pengaturan pemanggilan para pihak secara sah dan patut sebagaimana diatur dalam HIR dan RBG. Perbedaan pertama adalah terkait bentuk panggilan yang semula harus tertulis dalam HIR dan RBG menjadi tidak harus tertulis karena berbentuk elektronik. Perbedaan kedua adalah terkait tata cara pemanggilan, dalam HIR dan RBG Jurusita harus mengantarkan exploit dan menemui secara langsung yang bersangkutan di domisili hukumnya. Namun dalam e-summons Jurusita tidak harus mengantarkan exploit dan bertemu langsung dengan yang bersangkutan melainkan dilakukan secara elektronik melalui sistem $e$-court ke domisili elektronik yang bersangkutan.

Meskipun e-summons hanya bisa dilakukan dengan sepersetujuan pihak, namun tetap saja dapat dikatakan telah terjadi disharmonisasi antara pengaturan pemanggilan para pihak yang sah dan patut dalam HIR dan RBG dengan pengaturan pada PERMA No. 1 Tahun 2019.

Dari perspektif peraturan perundangundangan sebagaimana diatur dalam Pasal 7 ayat (1) Undang-Undang Nomor 12 Tahun 2011 tentang Pembentukan Peraturan Perundang-Undangan, idealnya ketika hendak mengganti norma dalam suatu jenis peraturan perundang-undangan maka penggantinya haruslah jenis peraturan perundang - undangan yang sama. Jika hendak mengganti norma dalam HIR dan RBG yang mana dapat disamakan dengan undang - undang maka penggantinya haruslah berupa undang - undang juga bukan dengan bentuk PERMA yang pada hakikatnya bersifat internal.
Lebih lanjut, bila dikaji dalam konteks asas - asas hukum, asas lex specialis derogat legi generalis yang bermakna bahwa aturan hukum yang khusus akan mengesampingkan aturan hukum yang umum tidak dapat diterapkan dalam pertentangan pengaturan pemanggilan sah dan patut antara HIR dan RBG dengan PERMA.

Hal ini didasari oleh pendapat Bagir Manan yang menyatakan bahwa lex specialis derogat legi generalis hanya dapat diterapkan dalam kondisi sebagai berikut (Manan, 2004): (a) Ketentuan-ketentuan yang didapati dalam aturan hukum umum tetap berlaku, kecuali yang diatur khusus dalam aturan hukum khusus tersebut; (b) Ketentuan-ketentuan lex specialis harus sederajat dengan ketentuan-ketentuan lex generalis; (c) Ketentuan-ketentuan lex specialis harus berada dalam lingkungan hukum (rezim) yang sama dengan lex generalis.

Berdasarkan syarat - syarat di atas terlihat bahwasanya PERMA mengenai $e$ court tidak memenuhi syarat yang kedua jika ingin disebut sebagai lex specialis dari HIR dan RBG. Sebagaimana yang dipahami bahwasanya tentu HIR dan RBG yang setara dengan undang-undang tidak bisa diderogate normanya oleh jenis peraturan perundang-undangan yang tidak sederajat, dalam hal ini adalah PERMA.

Dari uraian di atas dapat disimpulkan bahwasanya berdasarkan perspektif peraturan perundang-undangan PERMA tidak dapat menggantikan norma yang diatur oleh HIR dan RBG. Namun, jika ditinjau dari perspektif ajaran cita hukum Gustav Radburch yakni asas kepastian hukum, keadilan dan kemanfaatan maka kondisi ini dapat dimaklumi (Wantu, 2007). Asas utama yang mendasari pemakluman ini adalah asas kemanfaatan. Dimana suatu produk hukum atau peraturan pada pokoknya harus mampu menjadi jawaban dan solusi bagi persoalan yang ada di masyarakat.

Dalam konteks ini realitas yang terjadi di Indonesia tidak memungkinkan proses pembentukkan undang - undang berjalan 
dengan cepat. Hal ini dapat terlihat dari hasil riset Forum Masyarakat Peduli Parlemen (Formappi) yang menemukan fakta bahwasanya Dewan Perwakilan Rakyat (DPR) periode 2014-2019 hanya mampu mengesahkan 35 RUU Program Legislasi Nasional (Prolegnas Prioritas) dari total 189 RUU, artinya DPR hanya mampu mengesahkan kurang dari 20\% Prolegnas Prioritas (Fitra, S., 2019).

Melihat kondisi ini MA sebagai pemegang kekuasaan kehakiman tentu berada dalam kondisi yang dilematis. Di satu sisi MA dituntut untuk memiliki peradilan yang berbasis teknologi dan mengikuti perkembangan zaman guna meningkatkan kualitas pelayanan publik di pengadilan. Namun di sisi lain ketika membuat suatu kebijakan yang inovatif seperti $e$-court MA terbentur dengan regulasi lama seperti HIR dan RBG.

Oleh karena itu sudah saatnya para pemangku kepentingan bersinergi guna merumuskan suatu produk hukum acara perdata nasional yang up to date sehingga efektifitas dan efisiensi peradilan dapat diwujudkan.

\section{Simpulan}

Penerapan e-court di PN Palembang dan PN Surabaya secara umum telah dapat menciptakan efisiensi dan efektifitas. Hal ini terlihat dengan digunakannya secara masif tiga fitur dari e-court, yakni $e$-filing, eSKUM dan e-payment dan terbukti dapat mengurangi antrian pendaftaran perkara di kedua PN tersebut.

Fitur e-summons dan e-litigation belum dapat terlaksana dikarenakan ketidaktahuan pengguna peradilan terhadap keuntungan menggunakan fitur tersebut. Selain itu, untuk fitur e-litigation masih dalam proses penyediaan infrastruktur pendukung oleh pengadilan.

Keberadaan e-summons sebagai salah satu fitur $e$-court yang diatur dalam PERMA dalam kacamata tata peraturan perundangundangan sebenarnya bertentangan dengan pengaturan mengenai panggilan yang sah dan patut menurut HIR dan RBG dikarenakan ketidaksetaraan antara HIR dan RBG dengan PERMA.

Dalam perspektif asas kemanfaatan hal ini dapat dimaklumi mengingat inovasi dalam meningkatkan pelayanan di pengadilan sangat dibutuhkan sementara proses penyusunan peraturan perundang undangan terkait hukum acara perdata di DPR memakan waktu yang lama. Oleh karena itu PERMA yang secara substansi bertentangan dengan HIR dan RBG selama itu bertujuan untuk meningkatkan kualitas layanan pengadilan, maka dapat diberlakukan.

\section{DAFTAR PUSTAKA}

Asikin, Z. (2004). Pengantar Metode Penelitian Hukum. Jakarta: Raja Grafindo Persada.

Cole-O Lee, R. . (1986). Fundamental of the Environment of Business. New York: Mc. Graw-Hill Book.

Djais, M. ; R. M. J. K. (2012). Membaca dan Mengerti HIR Edisi Revisi. Semarang: Badan Penerbit Universitas Diponegoro.

Fitra, S., ; D.H.Jayani. (2019). Mengukur Kinerja DPR Lama dan Harapan untuk DPR Baru. Retrieved from https://katadata.co.id/telaah/2019/10/03/ mengukur-kinerja-dpr-lama-danharapan-untuk-dpr-baru

Hairi, P. J. (2011). Antara Prinsip Peradilan Sederhana, Cepat dan Berbiaya Ringan dan Gagasan Pembatasan Perkara Kasasi. Jurnal Negara Hukum, 2(1), 152.

Hidayat, R. (2019). MA Harus Fokus Pembenahan Pelayanan Publik di Pengadilan. Retrieved from https://www.hukumonline.com/berita/b aca/lt57b6fbf0efdf6/ma-harus-fokuspembenahan-pelayanan-publik-dipengadilan/

Mahkamah Agung. (2019a). Buku Panduan E-Court. Jakarta: Mahkamah Agung. 
Mahkamah Agung. (2019b). Peta E-Court Peradilan Umum. Retrieved from https://ecourt.mahkamahagung.go.id/ma pecourt_umum

Manan, B. (2004). Hukum Positif Indonesia. Yogyakarta: UII Press.

Prasetyo, A. (2019). Wawancara Hakim PN Palembang pada tanggal 7 - 8 Agustus 2019, Palembang. Palembang: Pengadilan Negeri.
Riyanto, R. . (2019). Modul 1 Sejarah, Sumber dan Asas - Asas Hukum Acara Perdata. Jakarta: Universitas Terbuka.

Wantu, F. . (2007). Antinomi Oleh Penegakkan Hukum Oleh Hakim. Jurnal Mimbar Hukum, 19(3), 388.

Wibowo, A. . (2019). Wawancara Staf Sub Bagian Perencanaan, Pelaporan dan Teknologi Informasi PN Surabaya pada tanggal 26 September 2019. Surabaya. 